\title{
Strategic Management System as The Internationalization Policy of Indonesian Islamic Higher Education
}

\author{
Irawan \\ Postgraduate Program \\ UIN Sunan Gunung Djati Bandung \\ Kampus II, Jl. Cimencrang-Panyileukan, \\ Bandung, Jawa Barat 40292 Indonesia \\ irawan@uinsgd.ac.id
}

\author{
Mahmud \\ Postgraduate Program \\ UIN Sunan Gunung Djati Bandung \\ Kampus II, Jl. Cimencrang-Panyileukan, \\ Bandung, Jawa Barat 40292 Indonesia \\ mahmud@uinsgd.ac.id
}

\begin{abstract}
In 2016, the Ministry of Religious Affairs of the Republic of Indonesia, the Directorate General of Islamic Education, and the Directorate of Islamic Higher Education, established a policy namely Strategic Management System (SMS). All colleges have to implement the system. But, the speculation that the policy wouldn't be continued appeared. This study aims to uncover the causes and to investigate the implementation progress and the effectiveness of the policy and its programs. The study used qualitative methods, including analysis of documents, interviews and observations. The results show that the Directorate of Islamic Higher Education has executed several stages i.e. 1) socializing; 2) mapping, and 3) rating. The components and the indicators are excellent to boost the colleges' performances as the first step of internationalizing Indonesian Islamic higher education. The Strategic Management System policy and its programs also give new perspective on Islamic educational management studies in which it is not only necessarily based on scriptures but also actual phenomena in Islamic education institutions.
\end{abstract}

Keywords-globalization, internationalization, Islamic higher education, strategic management system

\section{INTRODUCTION}

On February 17, 2017, the Ministry of Religious Affairs of the Republic of Indonesia, as department in charge of Islamic Higher Education (IHE) had mutated a number of officials of the Directorate of Islamic Higher Education. Director of Islamic Higher Education, Amsal Bakhtiar, as the initiator of the SMS policy was transferred to Research and Development Division, and became the chairman there. So, the current Director of Islamic Higher Education is Nizar (electronic document code: Do-e: D-01 \& 02). In the hand-over ceremony (21-2-2017), Bakhtiar did not affirm that implementation of SMS policy would be continued. Merely in one of his speech points, he left a massage that the Strategic Planning of IHE in 2016-2020 and 2021-2025 period had to be completed immediately. By this massage, implicitly, Bakhtiar wanted the SMS policy to be continued. Because, the SMS policy had been included in the draft of IHE's Strategic Planning (electronic document code: Do-e: D-02). However, the speculation that the policy wouldn't be continued appeared. IHE's institutions tardiness on rating data collection proved evidence that they have doubted the continuity of the program (electronic document code: Do-e: D-03). Since mutation occurred, the consultant whom campaigned the program actively, began to rarely checked the progress of the implementation of the program. Currently, the consultant is waiting for decision whether the contract will be continued or not. If the contract will be continued, as usual, the Director will send the letter of assignment to the team and the consultant in charge (interview document code: Do-IC-01).

Furthermore, the lack of experts in Islamic higher educational management and the not-yet established Islamic educational management as a science [1] have been causing the limitation in the research publication on the program. Until now, there are no experts on Islamic educational management field who specifically responded SMS policy and its program, either in research report or seminar. This research is the first academic activity which responses to the policy and the program. Many experts on Islamic education are more interested in academic field but lack in management. One of research report with the theme of Islamic educational management is that in the case of STAIN (State Academy of Islamic Studies) or IAIN (State Institute of Islamic Studies) transformation into UIN (State Islamic University). But it still focused on academic issue. The issue was academic wider mandate. It meant, some IAIN that transformed into UIN were allowed to develop not only Islamic studies programs but also natural and social science. This was called scientific nondichotomy of knowledge [2]. However, in managerialist era, epistemologically, the Islamic educational management research which focus on Islamic higher education institution as material object of the science is indispensable [3] [1]. IHE institutions have social, cultural, ideological, political and 
economic responsibilities to society itself. Referring to Indonesian National Education Law No. 20 of 2003, however, IHE, same as others higher education institutions, have three partite missions i.e. 1) organizing education or teaching; 2) research, and 3) community service or service functions of higher education [4][5]. So, basically, IHE had three important identity i.e. 1) teaching university; 2) research university, and 3) global university (world class university) [6][7]. Today and in the future, the challenges that will be faced by IHE are an increasingly fast, complex, sudden, unpredictable and uncontrollable changing in technology and a more marketoriented environment (fragmentation of production) [8][6]. IHE has to have a key and strategy to respond to the influence of globalization. IHE must be able to compete not only with other Islamic universities but also non-Islamic universities across the world, not only in academic area but also in management. In financial management for example, IHE must increase their income and manage it professionally. If not, corruption cases done by several leaders of Islamic higher education institutions will be reoccur (electronic document code: Do-e: Cs-01 \& 02). In knowledge management, IHE has to make Islamic global issues (terrorism and radicalism) as research materials and international conference themes. However, as Joko Widodo (Indonesian President) claimed, Indonesia had one of the best deradicalization programs in the world to curb radicalism and terrorism by prioritizing the use of soft approaches through the concept of Nusantara Islam i.e. progressive, tolerance and moderation as "a peaceful message" from ukhwa Islämiyya (Islamic brotherhood) [9].

This study aims to investigate the implementation progress and effectiveness of the policy and programs as a strategic system for IHE, to respond to the influence of (new) globalization. This study used a qualitative approach with case study type. The case was the policy of strategic management System for Indonesian Islamic Higher Education. Methods of collecting data were interviews, observation, and study of documents. Data was analyzed qualitatively. By data, the results can explain naturally whether SMS policy is important to be continued or not.

\section{METHOD}

Preparation for the approach was done by setting up the research framework that contained the focus of the study, the data collection methods used, and the participants involved. The research framework was elaborated in accordance to the instrument containing the aspects studied. The instruments were elaborated, then formed in details to resolve guidelines for all methods of data collection. Each contained a guide for interviews, observations and documents. The process of data collection, and the display of the results of a qualitative approach were carried out approximately in six months. Theses sequences of stages were intended to investigate the progress of the policy. Detailed data about the progress of the policy was analyzed as a basis to describe the condition of implementation the strategic management system (SMS) policy in Indonesian Islamic Higher Education. Observations were conducted to record the activities undertaken related to the SMS policy and programs. The researchers also made observations on the meetings, discussion, and establishment between the consultant and the committee of the program conducted in one of Islamic higher education. Interviews were conducted based on the outline instrument of literature reviews and forms of the programs with open answers. Interviews were conducted with one or more participants in the form of focus group discussion (FGD).

FGD was conducted on a designed program and socialization session, as one of the stage of the programs and done by researcher team. Interviews were also conducted in informal techniques. Participants involved in the interview were selected through the snowball method. Researchers determined the first participant as the key informants, and then he/she selected the next participants. In connection with that context, the researchers chose the chairman of the programs. The other participants involved were the education personnel and the consultant team of the program. Each of these various roles involved in the administration of the UIN, IAIN and STAIN as state Islamic higher education in Indonesia. Selection by this method was expected to produce a sufficient range of certain samples to describe the conditions in a variety of perspectives. The researchers were the main instruments (key instruments). Researchers also took on the role as participant observers.

The validity of the data was tested with the degree of credibility, transferability, dependability, and conformability. Based on the data collection, researchers got the rational conditions that occurred in the field. The description of the condition was the result of the rational credibility (internal validity) with members checking and triangulation techniques. Member checking was the result of interpretation and conclusion of the researchers' data presented to participants for approval. While triangulation was done by comparing and checking the level of trust of the information obtained from multiple sources (participants involved in formal and informal interviews), and methods for collecting the data (such as interviews, observation, and study of document). The data collected from the single case were analyzed qualitatively.

\section{RESULTS AND DISCUSSION}

One month before the hand-over ceremony (24-1-2017), a letter sent by the Directorate General of Islamic Education explained that all types of Indonesian Islamic higher education institutions i.e. UIN, IAIN, and STAIN had to fill the SMS questioners (the document of the Directorate General of Islamic Education's administration, document code: DoAd.IE-01).

The SMS policy assumed that every phase was not only as an identity change but also a series of governance improvements. The SMS policy was an effort to standardize the improvement of IHE's governance by improving and the changes of IHE's identity. Accordingly, these phases create a compliance, performance and high quality in management by 
improving IHE's governance, and global recognition university by changing IHE's identity. SMS should be presented in all phases, as shown in figure 1.

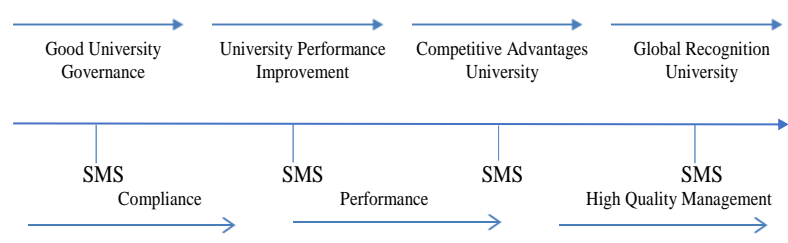

Figure 1. The SMS's Standardization

(adopted from SMS consultant document, July 12-2016)

The standardization of programs of the SMS policy were empowerment of Planning and Financial Division in all Indonesian state Islamic higher education institutions. The purpose of the program was to standardize the strategic planning and financial administration. In accordance with the priority programs, the leading sector of standardized strategic planning was Planning Division, while the financial administration was led by Internal Auditor Unit. The target of the program created "compliance" in internal IHE's institution. Actually, the program mechanism was less effective because the vices of Rector, especially academic and financial division as the supervisor of the two divisions mentioned before, didn't become important parts of the SMS policy. Then, the Internal Quality Assurance, and Research and Community Service Agency, as an executor of the program didn't yet structurally become parts of the policy. Financial division also was not in the part of the program, whereas this unit had been formerly present before Internal Auditor Unit was established. Briefly, in IHE institutions, the SMS policy and program had not been coordinated comprehensively as well as a macro understanding (Do-IHEI01; Do-IC-02, and observation notes document code: Do-OA$01)$.

Refer to the Ministry of Religious Affairs of the Republic of the Indonesia's hierarchical structure, the national structure of the SMS policy in Indonesian Islamic Higher Education is as shown in figure 2 ;

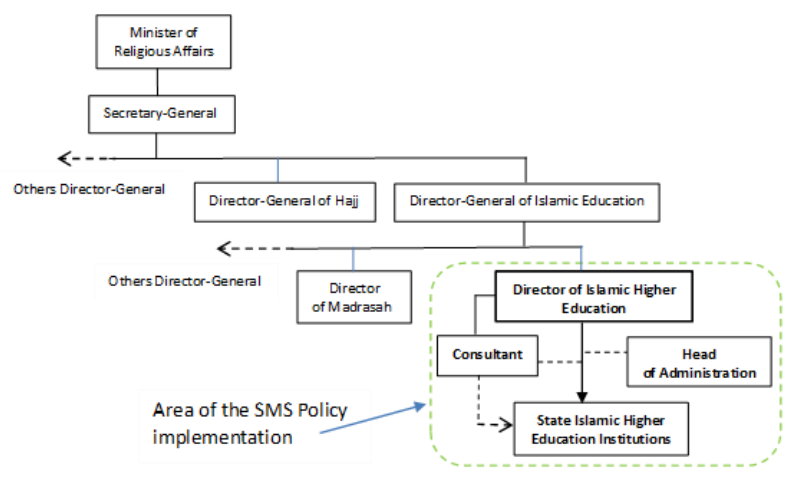

Figure 2. The National Structure of The SMS Policy in Indonesian Islamic Higher Education
In realizing the program, the former Director of Islamic Higher Education, Amsal Bakhtiar as coordinator and executor of the SMS policy, was assisted by consultant, Abdul Hamid Cebba and friends as well as Directorate of Islamic Higher Education Administrator, Abdullah Hanif only (see the area of SMS Policy implementation). General Director of Islamic Education was involved later. However, during the cooperation with the consultant, the former Director of IHE had implemented three phases of the SMS policy and its programs, as shown in figure 3 (adopted from consultant document July 12-2016, and interview document code: Do-IC03).

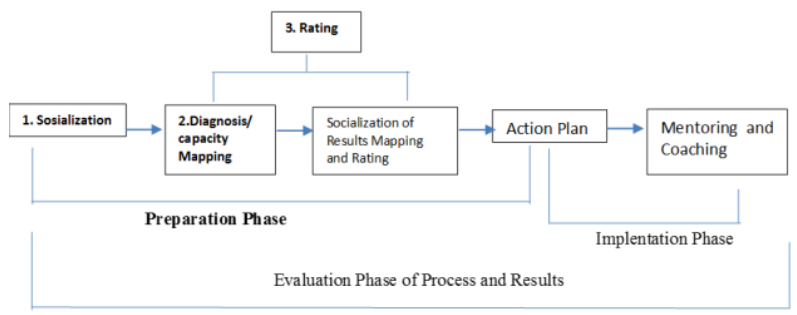

Figure 3. The Phases of SMS Policy Programs

The implemented actions of 1) socialization; 2) diagnosis or capacity mapping, and 3) rating were actually still in the preparation phase. There were ten from eleven UINs (without UIN Syarif Hidayatullah, Jakarta), two from IAINs (Raden Intan Lampung and Mataram), and two from STAINs (Kendari and Jember) participating in the socialization and diagnosis or capacity mapping action. Meanwhile, all colleges of State Islamic Higher Education in Indonesia were participating in the rating action, including UIN Syarif Hidayatullah Jakarta. Whereas, the rating was pseudo rating. It was not a real rating (interview document code: Do-IC-04).

There were two important instruments of the preparation phase i.e. 1) the SMS checklist components, and 2) SMS Rating Components and Indicators (the Directorate of IHE's administration document, document code: Do-Ad.IHE-02). There were IX items of the SMS checklist components, as shown in table 1 .

Table 1. Strategic Management System Checklist Components

\begin{tabular}{|l|l|}
\hline No & \multicolumn{1}{|c|}{ Component } \\
\hline I & Number of students \\
\hline II & Number of lecturers \\
\hline III & Number of administrators \\
\hline IV & Number of faculties \\
\hline V & Number of Study Programs \\
\hline VI & Institution Accreditation Grade \\
\hline VII & Large of Building Area \\
\hline VIII & Large of Area \\
\hline IX & Budgeting Calculation \\
\hline
\end{tabular}


Meanwhile, there were 28 items of components and their indicators of SMS (Do-Ad.IHE-03) rating, as shown in table 2.

Table 2. Strategic Management System Rating Components and Indicators

\begin{tabular}{|c|c|c|}
\hline No & Component & Indicator \\
\hline 1 & Internal Quality Assurance System & \multirow{10}{*}{$\begin{array}{l}\text { Good } \\
\text { University } \\
\text { Governance }\end{array}$} \\
\hline 2 & Role of the Internal Auditor Unit & \\
\hline 3 & Standard Operating Procedures & \\
\hline 4 & Performance Based Budgeting & \\
\hline 5 & Leadership & \\
\hline 6 & Lecturer Ratio & \\
\hline 7 & Management Information System & \\
\hline 8 & Student organizations & \\
\hline 9 & Organizational Behavior & \\
\hline 10 & Internalization of Islamic values & \\
\hline 1 & Scientific Development & \multirow{8}{*}{$\begin{array}{l}\text { University } \\
\text { Performance } \\
\text { Improvement }\end{array}$} \\
\hline 2 & Human Resource Performance & \\
\hline 3 & Unit Contributions & \\
\hline 4 & Length of Study Time & \\
\hline 5 & Grade-Point Average & \\
\hline 6 & Institution Accreditation Grade & \\
\hline 7 & Study Programs Accreditation Grade & \\
\hline 8 & Graduates Competitiveness & \\
\hline 1 & $\begin{array}{l}\text { Institutions Quality of Research and } \\
\text { Community Service }\end{array}$ & \multirow{6}{*}{$\begin{array}{l}\text { Competitive } \\
\text { Advantages } \\
\text { University }\end{array}$} \\
\hline 2 & International Indexed Journals & \\
\hline 3 & National Accredited Journals & \\
\hline 4 & International Publication & \\
\hline 5 & Foreign Student & \\
\hline 6 & Financial Sustainability & \\
\hline$\overline{1}$ & International Cooperation & \multirow{4}{*}{$\begin{array}{l}\text { Global } \\
\text { Recognition } \\
\text { University }\end{array}$} \\
\hline 2 & Foreign Lecturers Ratio & \\
\hline 3 & International Award Winner & \\
\hline 4 & Global Socioeconomics Impact & \\
\hline
\end{tabular}

The components have been grouped into four indicators. Every indicator contains not only internal environment variables but also external variables, particularly in Competitive Advantages University and Global Recognition University indicators.

The SMS consultant and former Director team has completed several works also, including; 1) the draft of Directorate Islamic Higher Education's strategic planning; 2) the guidelines of SMS implementation program; 3) Internal Audit Unit's coaching clinic, and 4) standardized strategic planning in several State Islamic Universities i.e. UIN of Sunan Gunung Djati, Bandung UIN of Wali Songo, Semarang and UIN Alauddin Makassar (Do-Ad.IHE-01; Do-IC-03, and Do-OA-02).

Refering to the data above, at least, there are four situations that inhibited the implementation of SMS Policy; First, the SMS policy and its programs were lack of regulatory support. It is important for the SMS policy executor to implement more regulatory oversight. Second, the SMS policy and its programs were less participation from Islamic educational management academics. It is important to publish the policy to IHE institutions and stakeholders [10]. The involvement of the relevant experts can support the socializing of SMS policy and its programs. For examples, the items of the SMS checklist component and Rating indicators, absolutely, were not discussed, whether the items are in accordance with the principles of Islamic indoctrination or not. Meanwhile, several items in the components and indicators match with the Principles of educational management from an Islamic perspective i.e. ikhlās (sincerity), sidq (truthfulness), amāna (trust), 'adl (justice), shūra (consultation and participation), and ihsān (forgiveness) [11]. So, everyone (Indonesian citizen, including 'ulama $\bar{a}$ or theologian) is welcome to contribute to the policy and program as well as to create a good governance citizenship in mezzo also national level [10]. Third, the SMS policy and its programs were poor in planning. Even, among the planning and implementation seemed overlapping. While actually, management system of education is how the top managers run the planned activity throughout the organization and how the planned changes can increase the effectiveness and health of the organization. Practical advices from top managers about the policy and program make future perspective, mission, results, long-term and short-term objectives clearer and more valuable due to the present of political support [12]. Four, the SMS policy and its programs were poor in commitment. Up to this point, the sustainability of SMS policy and program has not been clear yet. Even, the results of the rating have not yet been published too. There was disconnection between the former and the current IHE's Director. Whereas, the leaders' commitment is important in institutional performance to create a good IHE's governance performance [13][12][14].

In the Indonesian (national) context, refering to figure 2, to gain full support from the government, the top management of The Ministry of Religious Affairs should closely join the SMS policy and its program. So, the main person in charge of the policy would be the Minister of Religious Affairs. The supervisor in charge should be the General Secretary. Meanwhile, if the executor of the SMS policy is the Director of Islamic Higher Education, the SMS policy and its programs have the status quo in maintaining the perspective of the framing process. This perspective is to ensure the SMS policies legal force aspects. If the General Secretary comes supervisor, when the SMS policy needs urgent regulation, he has discretion to make more specific regulation and to create domestic (not only work unit i.e. UIN, IAIN and STAIN but 
also The Regional Office of Religious Affairs) civil effort. However in improving higher education (universities) governance and changing identity, it is important to recognize not only internal hierarchies (structure), but also global markets, and to find standardization parameter as an increasingly important form of coordination as well as to build of good university governance [15].

Referring to figure 1 , the use of the term "rating" that interchangeably with "mapping" as the strategy or methodological approach indicated extended outputs of the assessment process. It means, mapping and rating in figure 1 are included in preparation phase. Thus, several impacts of the strategy have been psychological. These impacts are raising the institutional self-esteem and interest in the SMS policy as socio-psychological phenomena, where all of Indonesian Islamic higher education institutions are devoted to raise the awareness to play more important role voluntarily. So, the aim of this phase as the promotion of preparation phase is to secure the sustainability of the success of SMS programs [16]. If the SMS policy and its programs stop in the middle, theoretically, it will be impossible for IHE institutions to build a good university governance, to be a world class university and to reach global and international level [17]. Fortunately, this policy and these programs were not really discontinued. There was an instruction letter from the General Director of Islamic Education, as the Director of Islamic Higher Education's supervisor to fill rating data template. It meant that the SMS policy didn't only have the opportunity to be continued but also expanded government oversight and regulation.

If the SMS policy is continued and done seriously, predictably, in the future, SMS's rating phase will be the real parameter of Indonesian IHE's ranking, similar to the one conducted by The Ministry of Research, Technology, and Higher Education of the Republic of Indonesia. In 2015, their version of national ranking ranked 3.320 Indonesian Higher Education Institutions without involving Indonesian Islamic Higher Education under The Ministry of Religious Affairs. However according to Ranking Web of Universities, some of IHE institutions are in fairly competitive positions i.e. UIN Syarif Hidayatullah Jakarta $\left(31^{\text {th }}\right)$, UIN Sunan Ampel Surabaya $\left(37^{\text {th }}\right)$, and UIN Maulana Malik Ibrahim Malang $\left(38^{\text {th }}\right)$. Even, there are eight state IHE institutions that entered the top 100 universities in Indonesia [18]. However, the ranking schemes have brought a shift in the geopolitics and geo-economics of higher education to the international level [19] particularly in Islamic higher education area. The national ranking version is based on the following quality criterions i.e. a). human resources, b) management, c) student activities, and d) research and scientific publication [20]. Essentially, these criterions are similar to the SMS rating components and indicators.

Components in table 1 (only 9 items) are less complete, complex and wide-ranging than they are in table 2 (28 items). In basic model of strategic management, items of the SMS component checklists in table 1 are in environmental scanning element. Environmental scanning is the monitoring, evaluating, and disseminating information from the external and internal environments to key people within the corporation [21]. Most of components in table 1 are still in the internal environmental scanning (number of students, lectures, administrators, faculties, study programs, and size of building and area). Only two items belong to external environmental scanning (Institution Accreditation Grade and Budgeting Calculation). So, in table 1, the instruments of SMS checklists still focus on internal assessment. The internal assessment of the institutions consists of variables (strengths and weaknesses) that are within the organization itself [22]. They include the institution's structure, culture, and resources. So, SMS checklist components are good to build internal characteristics such as self-maintenance, self-reliance, selfconfidence, discipline, hard work, rationalism, innovation, environmental protection, respecting structure, honoring the cultural and ethnic heritage, reading pleasure, increasing of productivity and competitiveness [12].

Conversely, referring to table 2, SMS policy and its programs seemed to have planned to describe the process of reaching IHE's vision and mission from existing situation to a desirable situation which outline the university organization's future (good governance, performance improvement, competitive advantages, and global recognition). Table 2 shows that the external environment consists of variables (opportunities and threats) that are out of the organization (globalization and internationalization issues).

Today, globalization and internationalization are major drivers of change in higher education systems globally (Knight 2008) [23]. Globalization is a key of social and economic trend and force for of change, impacting society in its broadest sense [5]. Indonesian Islamic higher education as part of the society, has to respond globalization and internationalization to increase in demand for colleges worldwide. SMS policy and its programs can be used as the step to reach from it, but the term of globalization should be replaced with the term of IHE 'internationalization'. However, many Indonesian people have linked globalization with the capitalism and commercialism. Accordingly, the spirit of globalism in Indonesian IHE by SMS policy and its programs can be regarded as only an attempt to commercialize Islamic education. By contrast, internationalization in Indonesian IHE can be regarded as the effort to intensify internationalization processes of service, curriculum, student, research, teaching etc. that will result in making the Indonesian IHE product more attractive and help to open access in global markets and exchange of information at high speed around the world.

The external variables form the context within which the corporation exists. They are not usually within the short-run control of top management. These variables form the context in which work is done. Any international plan should not only be internationalized or globalized but also reflect the suitable features and expectations of the local and national community [24]. Due to excellent recognition of the external environment, they can help organization boost its performance [12][21][15]. 
Figure 1 shows that the goal of SMS policy is not only improving IHE performance but also identity changing (see figure 1). The identity changing is a continuum program not a discrete. The continuum identity changes in IHE can be described from teaching or education, research to service all people, progressively or gradually, and vice versa. In global context, that is clear that everything is impacted by international economic development (globalization) in varying ways and degrees. So, when the Islamic higher education institutions want to globalize and internationalize their campus, have not to take out of teaching activities and focus on research or service people only. This way will undermine the professional qualities that should be most expected and prized by the world class university i.e. intrinsic motivation, creativity, love of knowledge and teaching in all of its expressions, and full dedication to the welfare of students [25].

Referring to Indonesian National Education Law No. 20 of 2003, in social perspective, identity must be viewed as being socially constructed in many ways and not given. Identity is a project and entails (1) positionality, in relation to others and doing so make distinctions between self and other; (2) performativity, involve action and can be viewed as sets of practices; (3) situation in a context; and (4) mostly discursive construction in narratives and other modes of communication [26]. Because identities are frequently overlapping, not fixed, and an on-going process of negotiation, so institutions of higher education (universities) can be theorized in terms of a notion of process, with constantly responding to external and internal demands and pressures (from the state, market, law, research funders) and they are translated into internal pressures as in managerialism, bureaucratization, evaluation and training. In addition, universities are multi-level institutions, with particularly complex systems of governance. Universities (higher education) have become 'liquid' organizations (Bauman 2001) in varying degrees [26].

\section{IV.CONCLUSION}

Based on the results, there are four obstacles in implementing of the SMS policy and its programs i.e. 1) the lack of regulatory support; 2) less in academic participations; 3) poor planning; and 4) poor commitment. However, the Directorate General of Islamic Education had executed several programs i.e. 1) socializing; 2) mapping, and 3) rating. These programs were still in the preparation phase. So, the policy and its programs need to be forwarded to the next step, that is implementation phase. The SMS policy has an internationalization vision that IHE should become the world class university. The SMS policy has two internationalization missions to achieve the vision i.e. improving of IHE's governance to get high performance and competitive advantages, and to change IHE's identity from teaching university to research university. The SMS policy has a good prospect to become an international Islamic higher education ranking institution in the world, because such institution is currently not available yet. The SMS policy gives a new perspective to the Islamic educational management field of studies that the researches are not only necessarily based on scriptures but also actual phenomena in Islamic education institutions.

\section{ACKNOWLEDGMENT}

Through this article, authors would like to thank to Amsal Bakhtiar, Nizar as the former and current Directors of Islamic Higher Education, Hamid Cebba and friends as the consultant team, Abdullah Hanif as Head of Administrator of the Directorate of Islamic Higher Education, for cooperating and the willingness of being the key informant for the research. So, I say thank also to Rector of UIN Sunan Gunung Djati Bandung for research financial assistance. Hopefully, the later research can run well and have an impact on the policy and program quality.

\section{REFERENCES}

[1] P. Buckley and Irawan, "The Scientific Paradigm of Islamic Education Management: Phenomenology Perspective," J. Pendidik. Islam, vol. 1, no. 2, p. 28, 2015.

[2] Irawan, "The Change of Organizational Culture of State Islamic Hgher Education Indonesia," in Conference Proceedings: Annual International Conference on Islamic Studies (AICIS) XII, $5-8$ November 2012, Surabaya - Indonesia., 2012, p. 3280.

[3] M. Thrupp and R. Willmott, Education Management in Managerialist Times. Open University Press, 2003.

[4] Undang-Undang Republik Indonesia Nomor 20 Tahun 2003. .

[5] J. Taylor, "The Response of Governments and Universities to Globalization and Internationalization in Higher Education," in Globalization and Internationalization in Higher Education Theoretical, Strategic and Management Perspectives, F. Maringe and N. Foskett, Eds. London: Continuum International, 2010, p. 84.

[6] M. Shattock, Managing Universities and Colleges: Guides to good practice Managing Universities and Colleges: Guides to good practice in Higher, First publ. London: Open University Press, 2006.

[7] I. F. Aguillo, "Methodology," Januari, 2017. [Online]. Available: http://www.webometrics.info/en/Methodology. [Accessed: 31-May2017].

[8] R. Baldwin, "What Populism Gets Wrong About Globalization," Bloomberg, $2017 . \quad$ [Online]. Available: http://www.hup.harvard.edu/catalog.php?isbn=9780674660489. [Accessed: 23-May-2017].

[9] H. Halim, "Jokowi calls for unity," The Jakarta Post, 22-May, p. 1, 2017.

[10] G. G. Peek et al., "Framing a Public Issue for Extension: Challenges in Oil and Gas Activity," J. Ext., vol. 53, no. 5, p. 5FEA1.

[11] M. Alkrdem and A. Alqahtani, "Educational Management in the Light of Islamic Standards," Br. J. Educ. Soc. Behav. Sci., vol. 14, no. 3, pp. 1-9, 2016.

[12] S. J. Amoli and F. Aghashahi, "An Investigation on Strategic Management Success Factors in an Educational Complex," Procedia - Soc. Behav. Sci., vol. 230, no. May, pp. 447-454, 2016.

[13] K. Rose, M. T. Miller, and K. Kit, “Organizational Citizenship Behavior In Higher Education: Examining The Relationships Between Behaviors and Institutional Performance," J. High. Educ. Manag., vol. 31, no. 1, pp. 14-27, 2016.

[14] S. J. Spinelli, "Leadership and Institutional Change In Higher Education," J. High. Educ. Manag., vol. 31, no. 1, pp. 131-143, 2016. 
[15] R. King, Governing Universities Globally Organizations, Regulation and Rankings. Cheltenham, Massachusetts: Edward Elgar, 2009.

[16] S. Gobbi, V. Puglisi, and A. Ciaramella, "A rating system for integrating building performance tools in developing countries," in Energy Procedia 96 (SBE16 Tallinn and Helsinki Conference), 2016, pp. $333-344$.

[17] V. R. Yeravdekar and G. Tiwari, "Internationalization of Higher Education in India: How Primed is the Country to Take on Education Hubs?," Procedia - Soc. Behav. Sci., vol. 157, pp. 165$182,2014$.

[18] “Indonesia," January Edition 1.1 (final), 2017. [Online]. Available: http://www.webometrics.info/en/Asia/indonesia. [Accessed: 27May-2017].

[19] K. Zaman, "Quality guidelines for good governance in higher education across the globe," Pacific Sci. Rev. B Humanit. Soc. Sci., vol. 1, no. 1, pp. 1-7, 2015.

[20] "SK Klasifikasi dan Pemeringkatan Perguruan Tinggi di Indonesia Tahun 2015," 3 Februari, 2015. [Online]. Available: http://www.dikti.go.id/sk-klasifikasi-dan-pemeringkatan-perguruantinggi-di-indonesia-tahun-2015/. [Accessed: 25-May-2017].

[21] T. L. Wheelen and J. D. Hunger, Strategic Management and Business Policy - Toward Global Sustainability, vol. Thirteenth. Pearson, 2012.

[22] M. Fooladvand, M. H. Yarmohammadian, and S. Shahtalebi, "The Application Strategic Planning and Balance Scorecard Modelling in Enhance of Higher Education," Procedia - Soc. Behav. Sci., vol. 186, pp. 950-954, 2015.

[23] F. Popescu, "South African Globalization Strategies and Higher Education," Procedia - Soc. Behav. Sci., vol. 209, no. July, pp. 411418, 2015.

[24] F. B. Ardakani, M. H. Yarmohammadian, A. A. F. Abari, and K. Fathi, "Internationalization of higher education systems," Procedia Soc. Behav. Sci., vol. 15, pp. 1690-1695, 2011.

[25] T. J. Tighe, Who's in charge of America's research universities: a blueprint for reform. Albany: State University of New York Press, 2003.

[26] R. Barnett and R. Di Napoli, Eds., Changing Identities in Higher Education, First publ., vol. 56, no. 2. New York: Routledge, 2008. 